\title{
Improving the efficiency of lambari production and diet assimilation using integrated aquaculture with benthic species
}

\author{
Aline M. Marques ${ }^{1}$; Andre Z. Boaratti ${ }^{1}$; Dalton Belmudes ${ }^{1}$; Julia R. C. Ferreira ${ }^{1}$; \\ Paulo V. L. Mantoan ${ }^{1}$; Patricia Moraes-Valenti ${ }^{1}$; Wagner C. Valenti ${ }^{1}$ \\ ${ }^{1}$ Aquaculture Center and CNPq, UNESP_São Paulo State University, São \\ Paulo 14884-900, Brazil; am.marques@unesp.br, andre.z.boaratti@unesp.br, \\ dalton.belmudes@gmail.com, julia.raquel@unesp.br, \\ paulovictormantoan@hotmail.com, moraes.valenti@unesp.br \\ Correspondence: w.valenti@unesp.br
}

\section{Abstract}

A single farmed fish species assimilates about $20 \%$ of the nutrients in the supplied diet. This study evaluated if the culture of complementary ecologicalfunction species can recover nutrients dispersed into the water and transform them into high-valued biomass. A completely randomized experiment was designed with three treatments and four replications of each production system: monoculture of lambari (Astyanax lacustris); integrated aquaculture of lambari and Amazon river prawn (Macrobrachium amazonicum); and integrated aquaculture of lambari, Amazon river prawn, and curimbatá (Prochilodus lineatus). Fingerlings of lambari $(0.8 \pm 0.8 \mathrm{~g})$ were stocked in twelve earthenponds $(0.015 \mathrm{ha})$ at the density of $50 \mathrm{fish} \mathrm{m}^{-2}$. Eight ponds, were stocked with juveniles of Amazon river prawn (1.1 $\pm 0.2 \mathrm{~g}$ ) at the density of 25 prawn $\mathrm{m}^{-2}$. Four of these eight ponds were stocked with curimbatá fingerlings $(0.2 \pm 0.1 \mathrm{~g})$ at a density of 13 fish $\mathrm{m}^{-2}$. Only lambari was fed twice a day with an extruded commercial diet. The experiment lasted 60 days when lambari attained commercial size. The inclusion of prawn increased the total species yield from 1.8 to $2.4 \mathrm{tha}^{-1}$ cycle $^{-1}$ and reduced the feed conversion ratio (FCR) from 2.5 to 1.8. The inclusion of prawn and curimbatá increased the total yield to $3.2 \mathrm{t} \mathrm{ha}^{-1}$ cycle $^{-1}$ and reduced the FCR to 1.4. Therefore, the integrated culture of lambari, prawn, and curimbatá improves the use of space, water, feed, and benthic species can recover the large quantity of nutrients accumulated in the bottom of lambari pond production, converting them into high-nutritional and monetaryvalued biomass. 
Keywords: Astyanax; Macrobrachium; Prochilodus; IMTA; resources optimization; integrated aquaculture

\section{Introduction}

Worldwide aquaculture production surpassed 120 billion tonnes and USD 275 billion in 2019 [1]. This activity is one of the fast-growing food-producing sectors, increasing about $6 \%$ yearly in the past three decades, employing more than 20 million people [2]. Aquaculture is essential to meet the increase in animal protein demand and provide food security [3]. Recently, animal aquaculture based on allochthonous diets (fed aquaculture) surpassed unfed aquaculture [2]. Diet is the major operating cost in fed monoculture systems [4]. Besides, it is the primary waste source in fish and shrimp monocultures [5-7]. This situation is because a single species is not able to assimilate most diet nutrients and energy. In monocultures, the farmed species assimilates only $\sim 20 \%$ of the diet nutrients, while almost $80 \%$ are dispersed into the water as particulate matter or dissolved nutrients and transform into pollution [4].

Integrated systems are based on farming more than one species per pond, and then it is possible to occupy the three spatial dimensions and different ecological niches [4]. These systems promote synergistic interactions between farmed species. The available resources can be more efficiently used, shared, recycled, and converted into biomass of high commercial value, based on the economic circularity concept. These systems also promote animal welfare and reduce environmental impact [8,9]. The integrated multitrophic aquaculture (IMTA) system is based on the farming of species with different trophic levels and/or with complementary functions and economic potential. The IMTA systems generally combine fed species with extractive species. These species use food waste and residues from the production of the fed species to grow; thus, it is possible to recover nutrients and increase yield without increasing inputs [10]. Therefore, choose suitable species that showed compatibility and complementarity is crucial to improving aquaculture sustainability $[8,9]$. 
Lambari is a group of small native fish from Brazil common in natural freshwater. They have gained visibility and good acceptance in very profitable market niches, such as human food and live bait for sport fishing $[11,12]$. The yellow tail lambari (Astyanax lacustris, former $A$. bimaculatus) [13] has opportunistic omnivorous feeding habits, high reproductive rate, short life cycle, and easy management, showing high qualities for aquaculture $[14,15]$. Despite the recent increasing production [12] and significant interest, there are no established standard raising systems and practices for farming this specie. Fonseca et al. [15] recommend the IMTA to improve the sustainability of the yellow tail lambari production in Brazil. Amazon river prawn, Macrobrachium amazonicum, is another species with great potential for aquaculture and described as an excellent alternative to composing IMTA systems. This species is detritivore and omnivorous, ingesting macrozoobenthos, algae, dead plants, and other residues deposited on lakes and river bottoms [16], and has a benthic habit, which avoids competition with pelagic species. However, studies carried out previously showed that the nutrients accumulated on the pond bottom at the end of the integrated farming of pelagic fish and Amazon river prawn are still large, making it possible to include another bottom detritivorous species [17-22]. Therefore, the addition of a third detritivorous species should improve nutrient recovery in the integrated system composed of a fed pelagic fish and a benthic prawn.

Curimbatá, Prochilodus lineatus, is another indigenous species in Brazil also known as curimba or curimatã. This species is exploited by fisheries and aquaculture in different regions of South America [12, 23-27]. This is an iliophagus fish that feeds predominantly on fine-particle organic matter and periphyton over the bottom of rivers and lakes [28, 29]. Thus, curimbatá can be an excellent option for the IMTA system with yellow tail lambari and Amazon river prawn. Curimbatá was introduced in China and Vietnam, where it has been farmed in integrated culture [29].

Considering the above rationale, this study aimed to evaluate if the introduction of benthic species with complementary niche trophic in the culture of a pelagic fish would recover lost nutrients and increase the yield, improving the utilization of the supplied diet. Yellow tail lambari, Amazon river prawn, and curimbatá are excellent models to test this hypothesis because they have 
complementary food habits and occupy different spaces inside ponds. Yellow tail lambari swims in the water column close to the surface, curimbatá close to the bottom, and the Amazon river prawn walk on the bottom. In addition, they have economic importance, and thus, results can be applied to develop farm technology.

\section{Materials and Methods}

\section{Experimental design}

An experiment of monoculture and integrated cultures was carried out at the Crustacean Sector of Aquaculture Center (CAUNESP), São Paulo State

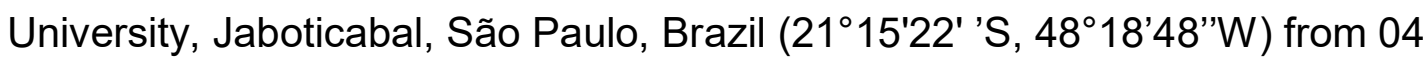
February 2019 to 04 April 2019. This period was necessary for the fish Astyanax lacustris to achieve the size for commercialization. A study was conducted in twelve earthen ponds with an area of $\sim 0.015$ ha and a depth of 1 $\mathrm{m}$. The ponds were initially drained, air-dried, and cleaned by removing the sediment accumulated on the bottom, resulting from previous cultures. Then, the ponds were filled with nutrient-rich water from two reservoirs that receive aquaculture effluents. The water was supplied throughout the culture to compensate for losses for seepage and evaporation.

The experimental design was completely randomized with three treatments and four replications. The treatments were monoculture of yellow tail lambari (A. lacustris) (LM), integrated culture of yellow tail lambari and Amazon river prawn (Macrobrachium amazonicum) (LP), and integrated culture of yellow tail lambari, Amazon river prawn, and curimbatá (Prochilodus lineatus) (LPC). The Amazon river prawn were obtained from CAUNESP from broodstock originated in the state of Pará, Amazonia (0114'30"S, 48 19'52'W). They were stocked at first $(5.4 \pm 0.4 \mathrm{~cm} ; 1.1 \pm 0.2 \mathrm{~g})$ in the ponds at a density of 25 prawns $\mathrm{m}^{-2}$ for the LP and LPC treatments. The prawn was stocked with this mass for the finishing stage of growth production. After 15 days, the curimbatá fingerlings $(2.5 \pm 0.3 \mathrm{~cm} ; 0.2 \pm 0.1 \mathrm{~g})$ were stocked at a density of 13 fish $\mathrm{m}^{-2}$ for LPC treatment. After that, the yellow tail lambari fingerlings $(3.4 \pm 0.8 \mathrm{~cm} ; 0.8 \pm 0.8$ g) were stocked at a density of 50 fish $\mathrm{m}^{-2}$ in all treatments. The fingerlings of both fish species were obtained from commercial hatcheries in the state of São Paulo, Brazil. 


\section{Feeding management}

The feeding for all treatments began after the stocking of the yellow tail lambari. Before that, the Amazon river prawn and curimbatá fed on natural biota [30-32]. A commercial diet for omnivorous fish was provided (36\% crude protein, granules of $2.3 \mathrm{~mm}$, recommended for fish juveniles). Feed was supplied just for yellow tail lambari twice a day at 10 a.m. and 04:30 p.m. Initially, the feeding rate was $10 \%$ of the yellow tail lambari biomass. When this fish attained mean biomass of $3.8 \pm 0.3 \mathrm{~g}$ (day 34 ), it was reduced to $5 \%$ of the biomass until the experiment's conclusion. The prawns and curimbatás fed on the diet remain and the wastes produced by the yellow tail lambari and natural biota.

\section{Water quality}

The water variables temperature, dissolved oxygen (DO), $\mathrm{pH}$, and conductivity were monitored daily at 08:00 a.m., using a probe YSI Professional Plus (Yellow Springs Instruments Company, Yellow Springs, USA) and maintained within the recommendations described in Boyd [33] for general aquaculture pond systems (Table 1). Aerators (Bernauer, model B-500 Aquahobby-monophasic) were used in all ponds to maintain adequate levels of dissolved oxygen. The aerators were turned on just when the dissolved oxygen was less than three $\mathrm{mg} \mathrm{L}^{-1}$. No significant differences among treatments were observed in all variables except for DO

Table 1. The mean \pm standard deviation of the water quality variables, measured in each treatment during culture. Inlet water had $534 \pm 284 \mu \mathrm{g} \mathrm{L}^{-1}$ of total nitrogen and $142 \pm 37 \mu \mathrm{g} \mathrm{L}^{-1}$ of total phosphorus. $\mathrm{LM}=$ lambari monoculture; $\mathrm{LP}=$ lambari and prawn integrated culture; LPC = lambari, prawn and curimbatá integrated culture.

\begin{tabular}{lcccc}
\multirow{2}{*}{ Variables } & \multicolumn{3}{c}{ Treatment } & \multirow{2}{*}{$\boldsymbol{P}^{*}$} \\
\cline { 2 - 4 } & LM & LP & LPC & \\
\hline Temperature $\left({ }^{\circ} \mathrm{C}\right)$ & $27.6 \pm 0.2$ & $27.9 \pm 0.2$ & $27.9 \pm 0.2$ & 0.252 \\
$\mathrm{DO}\left(\mathrm{mg} \mathrm{L}^{-1}\right)$ & $4.8 \pm 0.3^{\mathrm{b}}$ & $6.0 \pm 0.5^{\mathrm{a}}$ & $5.4 \pm 0.2^{\mathrm{b}}$ & 0.006 \\
$\mathrm{pH}$ & $8.0 \pm 0.1$ & $8.1 \pm 0.4$ & $8.1 \pm 0.2$ & 0.546 \\
Conductivity $\left(\mu \mathrm{S} \mathrm{cm}^{-1}\right)$ & $136 \pm 1$ & $134 \pm 1$ & $136 \pm 1$ & 0.162 \\
Nitrogen $\left(\mu \mathrm{L} \mathrm{L}^{-1}\right)$ & $425 \pm 186$ & $477 \pm 135$ & $462 \pm 136$ & 0.554 \\
Phosphorous $\left(\mu \mathrm{L} \mathrm{L}^{-1}\right)$ & $164 \pm 54$ & $192 \pm 58$ & $173 \pm 52$ & 0.216 \\
\hline
\end{tabular}


* $P$-value compare just water quality variables from treatments. Means followed by different letters in the same line indicate a significant difference between the treatments by ANOVA followed by the Fisher-LSD test $(P<0.05)$.

The water of each pond was sampled biweekly at 7 a.m. to measure total nitrogen and phosphorus concentrations. The total nitrogen and the total organic carbon were determined using oxidation catalytic combustion (Elementar - Vario TOC Select, USA). The total phosphorus was determined by the persulfate digestion method (4500-P B5) [34] to liberate orthophosphates associated with organic material (Table 1). The inlet water and the water inside the ponds during the culture were classified as eutrophic water, according to the classification of Brow and Simpson [35] because total nitrogen and total phosphorus concentration were within the ranges $390-6100 \mathrm{\mu g} \mathrm{L}^{-1}$ and 16-390 $\mu \mathrm{g} \mathrm{L}^{-1}$, respectively.

\section{Harvest and productivity data collection}

The ponds were drained 60 days after the yellow tail lambari stocking when all animals were harvested, and the survivors were counted. Samples of 100 prawns and 100 fish before and after the growth-out period were randomly sorted and measured using a caliper with a precision of $1 \mathrm{~mm}$ and weighed using a mass balance with a precision of $0.01 \mathrm{~g}$ (Marte, model AS2000C, Brazil). The means of the final individual mass and length, survival, feed conversion ratio (FCR), and yield per hectare of pond were calculated for each species in each pond. The FCR was calculated by dividing the total amount of commercial diet supplied in each pond during the experiment by the total biomass gain harvested in the same pond. The FCR was calculated based on the harvested biomass gain of the lambari, and, in the IMTA treatments, FCR was also computed based on the sum of the harvested prawn and fish biomass gain.

\section{Data Analysis}

The data were analyzed for normality and homoscedasticity of variances using Shapiro-Wilk and Levene tests, respectively. Then, the data were subjected to one-way ANOVA ( $F$-test). For significant differences, means were 
compared using the Fisher-LSD test. Differences were assumed as significant when $P<0.05$. Statistical analyses were performed on SigmaStat for Windows (Systat Software Inc., version 3.5).

\section{Results}

The final mean individual mass, total length, and survival of the yellow tail lambari showed no differences between treatments. In all treatments, the yellow tail lambari reached an average of $7.7 \mathrm{~g}$ and $7.4 \mathrm{~cm}$ of total length; survival was about $50 \%$, and the yield was about $1.9 \mathrm{t} \mathrm{ha}^{-1}$ (Table 2).

Table 2. Mass, length, survival, yield and FCR obtained in each treatment. Total annual yield was estimated presuming 5 production cycles. Initial size: yellow tail lambari $(A$. lacustris $)=3.4 \pm 0.8 \mathrm{~cm} ; 0.8 \pm 0.8 \mathrm{~g}$; Amazon river prawn $(M$. amazonicum $)=5.4 \pm 0.4 \mathrm{~cm} ; 1.1 \pm 0.2 \mathrm{~g}$; curimbatá $(P$. lineatus $)=2.5 \pm 0.3 \mathrm{~cm} ; 0.2 \pm 0.1 \mathrm{~g}$. $\mathrm{LM}=$ lambari monoculture; $\mathrm{LP}=$ lambari and prawn integrated culture; LPC = lambari, prawn and curimbatá integrated culture; FCR= Feed Conversion Ratio

\begin{tabular}{lccc}
\hline & LM & LP & LPC \\
\hline Total yield $\left(\mathrm{t} \mathrm{ha}^{-1} \mathrm{cycle}^{-1}\right)$ & $1.8 \pm 0.4^{\mathrm{c}}$ & $2.4 \pm 0.2^{\mathrm{b}}$ & $3.2 \pm 0.5^{\mathrm{a}}$ \\
Total anual yield $\left(\mathrm{t} \mathrm{ha}^{-1}\right)$ & 9 & 12 & 16 \\
Total FCR & $2.5 \pm 0.8^{\mathrm{a}}$ & $1.8 \pm 0.3^{\mathrm{ab}}$ & $1.4 \pm 0.3^{\mathrm{b}}$
\end{tabular}

\section{Astyanax lacustris}

FCR

$$
\begin{array}{ccc}
2.5 \pm 0.8 & 2.2 \pm 0.3 & 2.0 \pm 0.6 \\
7.7 \pm 0.8 & 7.8 \pm 0.9 & 7.7 \pm 0.8 \\
7.3 \pm 0.2 & 7.4 \pm 0.3 & 7.4 \pm 0.1 \\
46 \pm 8 & 48 \pm 9 & 56 \pm 14 \\
1.8 \pm 0.4 & 1.8 \pm 0.2 & 2.1 \pm 0.5
\end{array}
$$

Mean final mass ( $\mathrm{g}$ )

Mean final length $(\mathrm{cm})$

Survival (\%)

$46 \pm 8 \quad 48 \pm 9 \quad 56 \pm 14$

Yield $\left(\mathrm{t} \mathrm{ha}^{-1}\right)$

\section{Macrobrachium amazonicum}

Mean final mass (g)

Mean final length $(\mathrm{cm})$

Survival (\%)

Yield (t ha-1)

\section{Prochilodus lineatus}

Mean final mass $(\mathrm{g})$

Mean final length $(\mathrm{cm})$

Survival (\%)

Yield (t ha-1)

$$
\begin{array}{cc}
2.7 \pm 0.2 & 2.4 \pm 0.2 \\
6.8 \pm 0.2 & 6.6 \pm 0.2 \\
80 \pm 4 & 81 \pm 3 \\
0.6 \pm 0.1 & 0.5 \pm 0.0
\end{array}
$$

Different letters on the same line indicate the difference between treatments by ANOVA followed by the Fisher-LSD test $(P<0.05)$. 
The Amazon river prawn's final mean mass and length, survival, and yield have no statistical difference among the integrated culture treatments. The prawn's final size was about $2.6 \mathrm{~g}$ and $6.7 \mathrm{~cm}$, the mean survival was about $81 \%$, and the yield was $0.6 \mathrm{tha}^{-1}$. The curimbatá attained the final size of $6.1 \mathrm{~g}$ and $7.3 \mathrm{~cm}$, and the survival and yield were $70 \%$ and $0.5 \mathrm{tha}^{-1}$, respectively. The total yield (biomass of all species) increased with the addition of Amazon river prawn and curimbatá, being significantly higher in the LPC than other treatments. It ranged from $1.8 \mathrm{t} \mathrm{ha}^{-1}$ in LM to $3.2 \mathrm{t} \mathrm{ha}^{-1}$ in LPC. The yellow tail lambari feed conversion ratio (FCR) was similar between all treatments (Table 2). For the integrated culture system, the FCR decreased with the addition of prawn and curimbatá. It was significantly lower in the LPC than in the LM treatment, but there was no difference to the LP treatment. The FCR ranged from 2.5 in LM to 1.4 in LPC.

\section{Discussion}

The integrated culture of yellow tail lambari, Amazon river prawn, and curimbatá showed to be technically feasible, efficient, and productive. No adverse effect on the growth, survival, and yield of the yellow tail lambari was produced by the benthic species. Similarly, curimbatá did not affect the prawn's performance. All species developed well in stagnant earthen ponds using nutrient-rich water corroborating previous results $[31,32,36]$. Total annual highvalue biomass produced increased from $9 \mathrm{t} \mathrm{ha}^{-1}$ in lambari monoculture to $16 \mathrm{t}$ $\mathrm{ha}^{-1}$ in integrated culture, using the same space, amount of freshwater, feed, and other resources indicating a tremendous increase in system efficiency. Annually, $7 \mathrm{tha}^{-1}$ of nutrients were recovered from the environment and transformed into nutrient-rich human food and marketable product.

The yellow tail lambari is typically farmed in small earthen ponds $(0.03-0.3$ ha) for 3 to 4 months to attain 3 to $8 \mathrm{~cm}$ and are sold by US\$3.00/kg to processing plants or US $\$ 50.00$ per thousand individuals to bait-fish market [12]. Generally, farmers have low control and records of the cultures [15]. Available data (unpublished) indicate that survival ranges at about $50-60 \%$, productivity at $\sim 2 \mathrm{t} \mathrm{ha}^{-1}$ cycle $^{-1}$, and FCR from 1.6 to 2.1 in commercial farms. Therefore, the results obtained in the present study conform to the actual commercial-farm performance. Nevertheless, in one experiment conducted in 
small net-cages (160 L) during 45 days, Vilela and Hayashi [37] obtained 100\% survival. Henriques et al. [38] suggested that the Atlantic forest lambari (Deuterodon iguape) can attain 80 to $90 \%$ of survival raised in indoor recirculating tanks during 60 days. These data indicate the potential to increase the survival and yield of lambari culture by improving management practices. Mortality of yellow tail lambari in the present study and commercial farms may be caused by predation by birds and aquatic insects, susceptibility of the species to management, and the lack of a scientific-based farming protocol.

In the present study, yellow tail lambari reached the commercial size in 60 days in monoculture or integrated culture. This time is relatively short when compared to what is usual in commercial farms, which is 3 to 4 months [12]. This difference may be due to the accelerated growth of yellow tail lambari in warm and rainy seasons, the high-quality diet, or more controlled management, as observed in the present study. Therefore, performing 5 production cycles annually, as we simulated, seems feasible after minor improvements in the technology used in commercial farms. Amazon river prawns stoked as postlarvae in growth-out ponds generally spent about 120 days to reach the commercial size [39]. Thus, 2-months juvenile prawns should be stocked in integrated culture with yellow tail lambari as a strategy to combine and coincide both species cultivation periods. The curimbatá has a slow growth rate, but it should be traded as juveniles of different sizes to grow-out farms, bait-fish for the sportive fisheries market, or the environmental mitigation market [12,31]. Juveniles of different sizes produced in hatcheries are released annually into dam-impacted hydrological basins in Brazil, which support a massive artisanal fishery [12].

The present study corroborated that the Amazon river prawn can be raised with pelagic fishes in stagnant ponds filled with eutrophic or hypereutrophic water. Kimpara et al. [40] demonstrated that the use of nitrogen and phosphorus-rich water could be suitable for the monoculture of this prawn. Rodrigues et al. [36] demonstrated the feasibility of combining Amazon river prawn with Nile tilapia, and Dantas et al. [32] demonstrated the same, combining the prawn with tambaqui (Colossoma macropomum). All these studies used nutrient-rich water in stagnant ponds. Nevertheless, the yield of the Amazon river prawn is about $0.5 \mathrm{t} \mathrm{ha}^{-1} \mathrm{cycle}^{-1}$, when eating only diet 
residues and wastes of a pelagic fish, which is half of that obtained when prawn is fed with a specific commercial diet in densities below 40 prawns $\mathrm{m}^{-2}$ $[32,36,41]$ and the present results.

Curimbatá may compete with prawns by space and food on the pond bottom. However, no effect on prawn growth, survival, or yield was observed. These results indicate that the competition may be low, and no agonistic behaviors negatively impacted the culture when stocking 25 juvenile prawns and 13 fingerling curimbatás by $\mathrm{m}^{2}$. Probably, there is only a tiny overlap of trophic niches of both species. Curimbatá eats during the day [28], and Amazon river prawn eats alike during the day or at night [42]. Amazon river prawn eats mainly benthic organisms and large organic matter particles [16], while curimbatá ingest mud containing fine-particle organic matter, most particles lower than $105 \mu \mathrm{m}$, and periphyton that grow over inorganic particles $[28,43]$. This periphyton is composed mainly of microbial biomass [29] that extract carbon, nitrogen, phosphorous, and other nutrients from water and sediment, making them available for heterotrophic food webs.

The number and proportion of the unfed components of an integrated aquaculture system depend on the pelagic species' mass density because it provides residues and wastes. A co-stocking experiment that lasted 2 months showed that the yield of the Amazon river prawn stoked at 11 prawns $\mathrm{m}^{-2}$ together to $4 \mathrm{~g}$ tambaqui (the pelagic fed species), stocked at $1.4 \mathrm{~m}^{-2}$, decreased by $25 \%$ when 5 curimbatás $\mathrm{m}^{-2}$ were added [31]. However, total species biomass increased 35\%, and FCR decreased 30\%, showing that the yield of curimbatá compensates for the decrease in the prawn yield and the recovery of lost nutrients and energy increased. The higher biomass of lambari in the present experiment than the biomass of tambaqui in the study of Franchini et al. [31] was enough to provide the necessary wastes to support the density of Amazon river prawn and curimbatá with no adverse effect on the prawn growth.

We observed that adding Amazon river prawn to yellow tail lambari culture increased the annual yield from 9 to $12 \mathrm{t} \mathrm{ha}^{-1}$ and reduced FCR from 2.5 to 1.8. The addition of curimbatá, a second benthic species, with iliophagus food habit, increased annual yield to $16 \mathrm{t} \mathrm{ha}^{-1}$ e reduce FCR to 1.4 . This remarkable increase in efficiency by adding species with complementary ecological 
functions represented an improvement in nutrient recovery of almost $80 \%$. The present system is ranked as the maximum level of integration (level 5), according to the scale of Boyd et al. [4], which means that one cultivated species originates by-products, which are inputs for the others and vice versa. Yellow tail lambari produces wastes that down to the bottom, providing energy and nutrients for developing benthic communities. Amazon river prawn and curimbatá will feed on the aquatic biota or directly on the wastes contributing to the mineralization of organic matter. Their bioturbation creates an upwelling of nutrient-rich water, which will fertilize the water column, boosting the development of phytoplankton, which will be eaten by the zooplankton that is a nutrient-rich food to the yellow tail lambari. Therefore, the integrated system proposed creates a looping of nutrients, increasing recycling, assimilation, and the system's circularity. This scenario is provided by the compatibility of animals, which limits competition and agonistic behavior, and the complementarity exploited by the synergistic interaction between species leading to biomitigation and production processes $[9,44]$.

In conclusion, the integrated system proposed in the present study showed to be efficient in recovering nutrients spread in the water. This system also increases yield using the same inputs of feed, water, space and other natural resources as used in monocultures. The system transforms pollution into high-value marketable biomass, reducing the nutrients discharged in the effluents. The system also contemplates some important sustainability principles claimed by Valenti et al. [45], such as production based on the circular economy concept, reduction in using natural resources, increasing efficiency in assimilation nutrients, and allowing the producer to conquer different markets offering different products. The three species are native to Brazil, which brings some advantages, such as avoiding risks to biodiversity and exploring consolidated local markets [27, 46]. Furthermore, the experiment was performed in conditions very similar to the commercial farms, and therefore, the results are directly applicable, requiring few management adaptations to the lambari monoculture farms. This technology was patented on the Brazilian patent basis \# BR 102020 005641 7; 20 March 2020. Future studies should focus on determining nutrient and energy contents in the different pond ecological compartments, the stocking densities, the proportion of each species, 
and improving the management of the three-species culture to maximize efficiency.

\section{Funding}

This research was funded by São Paulo Research Fundation-FAPESP, processes \# 10/52210-3, 2018/15702-4, 2018/10363-7 and 2018/23993-9, National Council for Scientific and Technological Development-CNPq, processes \# 406069/2012-3, 306361/2014-0, 140910/2018-2,140911/2018-9 and 130870/2019-6, CAPES, process \# 88882.433723/2019-01 and CAPES EMBRAPA public notice: 15/2014, project number 24; FINEP, agreement $n$ o 01.10.0578.00/10.

\section{Conflicts of Interest}

The authors declare no conflict of interest.

\section{References}

1. FAO. Global Aquaculture Production. FAO Fisheries and Aquaculture Statistics. FAO: Rome, Italy, 2021. http://www.fao.org/figis/servlet/SQServlet?file=/usr/local/tomcat/8.5.16/figis/w ebapps/figis/temp/hqp_4125957264323673027.xml\&outtype=html (Accessed on 29 July 2021).

2. FAO. The State of World Fisheries and Aquaculture 2020. Sustainability in action. FAO: Rome, Italy, 2020.

3. Béné, C.; Barange, M.; Subasinghe, R.; Pinstrup-Andersen, P.; Merino, G.; Hemre, G. I.; Williams, M. Feeding 9 billion by 2050-Putting fish back on the menu. Food Security. 2015, 7(2), 261-274.

4. Boyd, C. E.; D'Abramo, L. R.; Glencross, B. D.; Huyben, D. C.; Juarez, L. M.; Lockwood, G. S.; McNevin, A. A.; Tacon, A. G. J.; Teletchea, F.; Tomasso Jr, J. R.; Tucker, C. S.; Valenti, W. C. Achieving sustainable aquaculture: Historical and current perspectives and future needs and challenges. Journal of the World Aquaculture Society. 2020, 51(3), 578-633.

5. Hardy, R. W.; Gatlin, D. Nutritional strategies to reduce nutrient losses in intensive aquaculture. In: Cruz-Suárez, L. E.; Ricque-Marie, D.; TapiaSalazar, M.; Gaxiola-Cortés, M. G.; Simoes, N. (Eds.). Avances en Nutrición 
Acuícola VI. Memorias del VI Simposium Internacional de Nutrición Acuícola. Cancún, Quintana Roo, México, 2002.

6. Tacon, A. G. J.; Forster, I. P. Aquafeeds and the environment: policy implications. Aquaculture. 2003, 226,181-189.

7. Mongirdas, V.; Žibienè, G.; Žibas, A. Waste and its characterization in closed recirculating aquaculture systems - a review. Journal of water security., vol. 3, article number: jws2017002, 2017.

8. Henares, M. N.; Medeiros, M. V.; Camargo, A. F. Overview of strategies that contribute to the environmental sustainability of pond aquaculture: rearing systems, residue treatment, and environmental assessment tools. Reviews in Aquaculture. 2020, 12(1), 453-470.

9. Thomas, M.; Pasquet, A.; Aubin, J.; Nahon, S.; Lecocq, T. When more is more: taking advantage of species diversity to move towards sustainable aquaculture. Biological Reviews. 2021, 96(2), 767-784.

10. Chopin, T.; MacDonald, B.; Robinson, S.; Cross, S.; Pearce, C.; Knowler, D.; Noce, A.; Reid, G.; Cooper, A.; Speare, D.; Burridge, L.; Crawford, C.; Sawhney, M.; Ang, K. P.; Backman, C.; Hutchinson, M. The Canadian Integrated Multi-Trophic Aquaculture Network (CIMTAN) - A Network for a New Era of Ecosystem Responsible Aquaculture. Fisheries. 2013, 38(7), 297-308.

11. Henriques, M. B.; Fagundes, L; Pretesse, M. L.; Silva, N. J. R.; Rezende, K. F. O.; Barbieri, E. Lambari fish Deuterodon iguape as an alternative to live bait for estuarine recreational fishing. Fisheries Management and Ecology. 2018, 25, 400-407.

12. Valenti, W. C.; Barros, H. P.; Moraes-Valenti, P.; Bueno, G. W.; Cavalli, R. O. Aquaculture in Brazil: past, present and future. Aquaculture Reports. 2021, 19, 100611.

13. Lucena, C. A.; Soares, H. G. Review of species of the Astyanax bimaculatus "caudal peduncle spot" subgroup sensu Garutti \& Langeani (Characiformes, Characidae) from the rio La plata and rio São Francisco drainages and coastal system of southern Brazil and Uruguay. Zootaxa. 2016, 4072(1), 101-125.

14. Ferreira, P. M. F.; Nascimento, L. S.; Dias, D. C.; Moreira, D. M. V.; Salaro, A. L.; Freitas, M. B. D.; Carneiro, A. P. S.; Zuanon, J. A. S. Essential 
oregano oil as a growth promoter for the yellow tail tetra, Astyanax altiparanae. Journal of the World Aquaculture Society. 2014, 45(1), 28-34.

15. Fonseca, T.; Costa-Pierce, B. A.; Valenti, W. C. Lambari Aquaculture as a Means for the Sustainable Development of Rural Communities in Brazil. Reviews in Fisheries Science \& Aquaculture. 2017, 25(4), 316-330.

16. Kensley, B. and Walker, I. Palaemonid Shrimps from the Amazon Basin, Brazil (Crustacea: Decapoda: Natantia). Smithsonian Contributions to Zoology. 1982, 362:1-27.

17. David, F. S.; Proença, D. C.; Valenti, W. C. Phosphorus budget in integrated multitrophic aquaculture systems with Nile Tilapia, Oreochromis niloticus, and Amazon River prawn, Macrobrachium amazonicum. Journal of the World Aquaculture Society. 2017, 48(3), 402-414.

18. David, F. S.; Proença, D. C.; Valenti, W. C. Nitrogen budget in integrated aquaculture systems with Nile tilapia and Amazon River prawn. Aquaculture International. 2017, 25(5), 1733-1746.

19. David, F. S.; Proença, D. C.; Flickinger, D. L.; Bueno, G. W.; Valenti, W. C. Carbon budget in integrated aquaculture systems with Nile tilapia (Oreochromis niloticus) and Amazon river prawn (Macrobrachium amazonicum). Aquaculture Research. 2021, 52(6), 1-13.

20. Flickinger, D. L.; Costa, G. A.; Dantas, D. P.; Moraes-Valenti, P.; Valenti, W. C. The budget of nitrogen in the grow-out of the Amazon river prawn (Macrobrachium amazonicum Heller) and tambaqui (Colossoma macropomum Cuvier) farmed in monoculture and in integrated multitrophic aquaculture systems. Aquaculture Research. 2019, 50(11), 3444-3461.

21. Flickinger, D. L.; Dantas, D. P.; Proença, D. C.; David, F. S.; Valenti, W. C. Phosphorus in the culture of the Amazon river prawn (Macrobrachium amazonicum) and tambaqui (Colossoma macropomum) farmed in monoculture and in integrated multitrophic systems. Journal of the World Aquaculture Society. 2020, 51:1002-1023.

22. Flickinger, D. L.; Costa, G. A.; Dantas, D. P.; Proença, D. C.; David, F. S.; Durborow, R. M.; Moraes-Valenti, P.; Valenti, W. C. The budget of carbon in the farming of the Amazon river prawn and tambaqui fish in earthen pond monoculture and integrated multitrophic systems. Aquaculture Reports. 2020, 17, 100340. 
23. Wright, J. P.; Flecker, A. S. Deforesting the riverscape: the effects of wood on fish diversity in a Venezuelan piedmont stream. Biological Conservation. 2004, 120, 439-447.

24. Taylor, B. W.; Flecker, A. S.; Hall Jr, R. O. Loss of a harvested fish species disrupts carbon flow in a diverse tropical river. Science. 2006, 313, 833-836.

25. Sampaio, L. A.; Ono, E.; Routledge, E. A. B.; Correia, E. S.; Moraes-Valenti, P.; Martino, R. C. Brazilian aquaculture update. World Aquacultulture. 2010, $35,41-68$.

26. Freire, K. M. F.; Machado, M. L.; Crepaldi, D. Overview of inland recreational fisheries in Brazil. Fisheries. 2012, 37 (11), 484-494.

27. Saint-Paul, U. Native fish species boosting Brazilian's aquaculture development. Acta of Fisheries and Aquatic Resources. 2017, 5(1), 1-9.

28. Fugi, R.; Hahn, N. S.; Agostinho, A. A. Feeding styles of five species of bottom-feeding fishes of the high Paraná River. Environmental Biology of Fishes. 1996, 46, 297-307.

29. Kalous, L.; Bui, A. T.; Petrtyl, M.; Bohlen, J.; Chaloupkova, P. The south American freshwater fish Prochilodus lineatus (Actinopterygii:

Characiformes: Prochilodontidae): new species in Vietnamese aquaculture. Aquaculture Research. 2012, 43, 955-958.

30. D'Abramo, L. R.; Sheen, S. S. Nutritional requirements, feed formulation, and feeding practices for intensive culture of the freshwater prawn Macrobrachium rosenbergii. Reviews in Fisheries Science. 1994, 2:1, 1-21, DOI: $10.1080 / 10641269409388551$.

31. Franchini, A. C.; Costa, G. A.; Pereira, S. A.; Valenti, W. C.; Moraes-Valenti, $P$. Improving production and diet assimilation in fish-prawn integrated aquaculture, using iliophagus species. Aquaculture. 2020, 521, 735048.

32. Dantas, D. P.; Flickinger, D. L.; Costa, G. A.; Batlouni, S. R.; MoraesValenti, P.; Valenti, W. C. Technical feasibility of integrating Amazon river prawn culture during the first phase of tambaqui grow-out in stagnant ponds, using nutrient-rich water. Aquaculture. 2020, 516, 734611.

33. Boyd, C. E. Water quality: an introduction. Springer Nature, Alburn, AL, USA, 2019. 
34. APHA (American Public Health Association). Standard methods for the examination of water and wastewater. APHA, $23^{\text {rd }}$ edition, Washington, DC, USA, 2017.

35. Brown, T.; Simpson, J. Managing phosphorus inputs to urban lakes: I.

Determining the trophic state of your lake. Watershed Protection Techniques, 2001, 3(4), 771.

36. Rodrigues, C. G.; Garcia, B. F.; Verdegem, M.; Santos, M. R.; Amorim, R. V.; Valenti, W. C. Integrated culture of Nile tilapia and Amazon river prawn in stagnant ponds, using nutrient-rich water and substrates. Aquaculture. 2019, 503, 111-117.

37. Vilela, C.; Hayashi, C. Desenvolvimento de juvenis de lambari Astyanax bimaculatus (Linnaeus, 1758), sob diferentes densidades de estocagem em tanques-rede. Acta Scientiarum. Biological Sciences. 2001, 23, 491-496.

38. Henriques, M. B.; Caeneiro, J. S.; Fagundes, L.; Castilho-Barros, L.; Barbieri, E. Economic feasibility for the production of live baits of lambari (Deuterodon iguape) in recirculations system. Boletim do Instituto de Pesca. 2019, 45(4), 516-524.

39. Marques, H. L. A.; Moraes-Valenti, P. Current status and prospects of farming the giant river prawn Macrobrachium rosenbergii (De $M$ an 1879) and the Amazon river prawn Macrobrachium amazonicum (Heller 1862)) in Brazil. Aquaculture Research. 2012, 43(7), 984-992.

40. Kimpara, J. M.; Rosa, F. R. T.; Preto, B. L.; Valenti, W. C. Limnology of Macrobrachium amazonicum grow-out ponds subject to high inflow of nutriente-rich water and diferente stocking and harvest management. Aquaculture Research. 2011, 42:1289-1297.

41. Moraes-Valenti, P.; Valenti, W. C. Effect of intensification on grow out of the Amazon River prawn, Macrobrachium amazonicum. Journal of the World Aquaculture Society, 2007, 38(4), 516-526.

42. Ibrahim, A. N. A. F.; Karplus, I.; Valenti, W. C. Social interaction in males of the Amazon river prawn Macrobrachium amazonicum (Heller, 1862) (Decapoda, Palaemonidae). Crustaceana. 2021, 94(3), 325-341.

43. Fugi, R.; Agostinho, A. A.; Hahn, N. S. Trophic morphology of five benthic feeding fish species of a tropical floodplain. Revista Brasileira de Biologia. 2001, 61(1), 27-33. 
44. Marques, H. L. A.; New, M. B.; Boock, M. V.; Barros, H. P.; Mallasen, M.; Valenti, W. C. Integrated freshwater prawn farming: state-of-the-art and future potential. Reviews in Fisheries Science \& Aquaculture. 2016, 24(3), 264-293.

45. Valenti, W. C.; Kimpara, J. M.; Preto, B. L.; Moraes-Valenti, P. Indicators of sustainability to assess aquaculture systems. Ecological Indicators. 2018, 88, 402-413.

46. Valladão, G. M. R.; Gallani, S. U.; Pilarski, F. South American fish for continental aquaculture. Reviews in Aquaculture. 2018, 10(2), 351-369. 